\title{
The Effect of Regional Development on The Sustainability of Local Irrigation System (A Case of Subak System in Badung Regency, Bali Province)
}

\author{
I Putu Sriartha ${ }^{1}$, Suratman$^{2}$, Sri Rum Giyarsih ${ }^{2}$ \\ 1) Departement of Geography Education, Ganesha University of Education, Singaraja \\ ${ }^{2)}$ Faculty of Geography, Gadjah Mada University, Yogyakarta \\ Corresponding E-mail : psriartha@yahoo.com
}

\begin{abstract}
This study was aimed at investigating the sustainability of subaks in the dynamics of regional development in the metropolitan area of Badung Regency, Bali Province. The data on subak sustainability were collected by using survey method in 69 subaks as the units of analysis, and the secondary data on the factors of regional development were collected by using document recording method. The data were analyzed by using quantitative decriptive technique, Analytical Hierarchy Process (AHP), and multiple linear regression. The results showed that the spatial distribution of subak sustainability levels forms cluster pattern with different dominations in short-, trantitional- and long- distance zones from the tourism center. The components/elements of Tri Hita Karana (THK) that constitute the first priority in subak sustainability protection are wet land conversion control and guarantee for irrigation water adequacy. It was found that five factors ot regional development have a strong influence on subak sustainability with $87.8 \%$ contribution, and the rest $(12.2 \%)$ is acounted by other factors outside the scope of this study.
\end{abstract}

Keywords : subak sustainability, Tri Hita Karana (THK), regional development.

\begin{abstract}
Abstrak
Tujuan penelitian adalah mengkaji keberlanjutan subak di tengah dinamika perkembangan wilayah di kawasan metropolitan Kabupaten Badung, Bali. Data keberlanjutan subak dikumpulkan dengan metode survai di 69 subak sebagai unit analisis, dan data sekunder faktor-faktor perkembangan wilayah dikumpulkan dengan metode pencatatan dokumen. Analisis data dilakukan dengan teknik deskriptif kuantitatif, Analytical Hierarchy Process (AHP), dan regresi linear berganda. Hasil penelitian menunjukkan bahwa sebaran spasial tingkat keberlanjutan membentuk pola mengelompok dengan dominasi yang berbeda di zona dekat, zona transisi, dan zona jauh dari pusat pariwisata. Komponen dan elemen $T H K$ yang menjadi prioritas utama perlindungan subak adalah pengendalian alih fungsi lahan sawah dan menjamin kecukupan air irigasi. Ditemukakan 5 faktor perkembangan wilayah yang berpengaruh kuat terhadap keberlanjutan subak, dengan kontribusi pengaruh sebesar $87,8 \%$ dan sisanya sebesar $12,2 \%$ dijelaskan oleh faktor lain di luar lingkup penelitian ini.
\end{abstract}

Kata kunci : keberlanjutan subak, Tri Hita Karana $(T H K)$, perkembangan wilayah.

\section{Introduction}

Subak is basically a Farmer-Managed Irrigation System Institution born of Balinese culture. Although it is derived from typical Balinese culture, various studies prove that subak can be used as a model of harmonious community life and a management of sustainable resources at scale of wider areas and communities. As stated by Ahimsa-Putra (1999), Susanto (1999), Windia (2002), and Sutawan (2008), subak is carried out based on the philosophy of Tri Hita Karana (THK) which has universal life values and can be transferred to other regions.
Application of local wisdom values of THK of subak has proved that subak is considered as the unique and the world's most effective local irrigation management (Geertz, 1979, 1980; Ostrom,1992; Ambler,1992; Lansing, 1987; Lorenzen, 2010), as stabilizer of social and cultural life and democracy model (Susanto, 1999, 2000; Ostrom,1992; Sutawan, 2005, 2008; MacRae and I.W.A. Arthawiguna, 2011), as regulator of ecosystem (Lansing and Therese A. De vet, 2012), as enabler of food security, as development of agricultural sustainability, and as application of good governance principle (Kasryno, dkk., 2003 ; Baharsyah, 2005; Sutawan, 2008). 
On June 29, 2012, United Nations through the United Nations Educational, Scientific and Cultural Organization (Unesco) has set subak as world cultural heritage that must be protected. UN considers that subak has outstanding universal values; one of them is the values of strong social bond (ANTARA, 2012).

Although subak has various advantages and has been considered as world cultural heritage, the problems encountered are getting heavier and more complex. Lorenzen (2010), MacRae and Arthawiguna, (2011), Bali Post (2014), noted some serious problems: the uncontrollable conversion of the rice terraces, the increase on irrigation scarcity, the high cost of facilities and production processes, the uncertain selling price of the harvests, the increased amount of the living cost, and the low appreciation of the young generation towards the agricultural sector. Rai and Menaka (2011) reported that the conversion of paddy field in Bali reached 560.1 - 1,000 ha/year. While Purnama (2009) found that water balance ratio in Bali reached $47 \%$, that it means almost a critical point.Those are supposed to be serious problems for the sustainability of subak.

The sustainability concept of subak refers to its basic philosophy, THK (Susanto, 1999; Mawardi, 1999; Sutawan, 2005, Windia, 2006, 2008). Literally, THK means three components that cause happiness/prosperity (Tri $=$ three, $H i t a=$ happiness, and Karana $=$ cause of). The three components are parhyangan (the relationship between mankind and God), pawongan (the relationship between mankind), and palemahan (the relationship between mankind and nature). Balinese society believes that creating harmonious relationship among those three components would instigate blissful/prosperous life. Practically, parhyangan, pawongan, and palemahan are reflected in cultural life, social and economic life, and technology and physical environment (rice terrace and water ecologies) respectively. The core philosophy of THK is in line with the concept of sustainable development, mainly in the development of sustainable agriculture proposed by SEARCA (1995).

Local government policies which extremely enhance tourism sector lead to rapid development of areas presented by a number of factors, such as the increasing number of transportation infrastructures that open the locational access, the increasing number and heterogeneity of demography, the density of the socio-economic facilities, the transformation of economic structure and agrarian culture to economic structure and manufacturing, trade, and tourism cultures. Bastakoti et al (2010) found that the local irrigation system managed by farmers has convincing ability in facing external growth pressure by creating beneficial strategies and adaptation and therefore it keeps maintaining its high performance. Different findings were stated by Susanto (1999), Alit et al (2006), and Lorenzen (2010), that the rapid growth of some areas, in terms of economic and tourism developments, on one hand, is economically profitable but on the other hand has threaten the sustainability of subak.

The focus of this research is to analyze the sustainability of subak irrigation system in the middle of the dynamic development of areas. Specifically, the aims of this research are: (1) to describe the spatial pattern of the level of subak sustainability, (2) to define the components and elements of THK determining the sustainability of subak, and to analyze the influence of factors of area development towards the sustainability of subak.

\section{Research Method}

This research applied survey method with three areas (Kuta, Kuta Utara, and Mengwi) situated in Badung regency as its research locations (sites). Other than as irrigated agricultural lands (rice terraces), those areas are enacted as metropolitan areas. The unit of analysis included 69 units of subak. The data of subak sustainability, components of THK and elements of $T H K$ as determining factors for the sustainability of subak were collected from the subak management board with group interview technique based on questionnaires and lists of statements prepared.

The data of area, number and width of subak, as well as factors contributing to the area development, covering 6 variables, were collected with document-recording technique from datastoring institutions such as Central Bureau of Statistics (Biro Pusat Statistik/BPS), Regional Development Planning Board (BAPPEDA), and Department of Highways and Irrigation (Dinas Bina Marga dan Pengairan) of Badung regency. Data unit of the 6 variables consisted of proximity of subak area to tourism center $(\mathrm{km})$, existence of road (weighted score $=$ score of the existence of road multiplied by the weight of road level), 
existence of socio-economical facilities (weighted score $=$ total of types of facilities multiplied by weight), population density (inhabitant(s)/ha), population growth $(\%)$, and percentage of nonagricultural families (\%). The data of the last four variables are at village level, while the unit of analysis is at subak area level. Therefore, the data obtained were transformed into subak area level by measuring the percentage of subak area contribution in village area.

The data analysis techniques for this research included quantitative descriptive analysis, analytic hierarchy process (AHP) analysis, and inferential statistical analysis. Quantitative descriptive analysis was used to explain the spatial pattern of subak sustainability level. The findings of the interviews comprised responses on questionnaires with the scores ranging from 1 to 4 ( 1 = very low, $2=$ low, $3=$ high, $4=$ very high).

The criteria for assessing subak sustainability level were set based on the maximum and minimum ideal average scores ranging from 1 to 4 . The scores were measured by dividing the total score with the numbers of questions. The total questions on subak sustainability were 61 , consisting of cultural sustainability (10 items), social sustainability ( 22 items), economical sustainability (12 items), technical sustainability (10 items), and natural-physical sustainability ( 7 items). On the basis of the ideal average scores, the measurement criteria for subak sustainability level were set, i.e. high sustainability (average score $>3$ ), medium sustainability (average score is 2-3), and low sustainability (average score < 2). Afterwards, empirical average score for the sustainability of each subak was linked to ideal criteria to indicate the position of subak sustainability level.

To describe the spatial pattern of subak sustainability level, the research areas were categorized into three zones on the basis of average distance of subak to Kuta tourism center. From the result of the calculation of distance using geographic information system (GIS) analysis, criteria for zoning were divided as follow: near zone (average distance $<9 \mathrm{~km}$ ), transition zone (average distance is 9-16 $\mathrm{km}$ ), and far zone (average zone $>16 \mathrm{~km}$ ). The data of subak sustainability were then visualized into a map, analyzed (their distribution special characteristics), interpreted and reviewed narrativeanalytically.

The data of measurement or perception on the importance level of components and elements of THK were indicated by the values of $1,3,5,7$, and 9, based on working principals of AHP expressed as matrix of pair comparisons (Saaty, 1994). The values have relative significance $(1=$ both compared elements are equally important, $3=$ one element is a little more important than another, $5=$ one element is more important than another, $7=$ one element is much more important than another, and $9=$ one element is extremely more important than another). The collected data were analyzed using AHP Expert Choice software.

The inferential statistical analysis applied in this research was called multiple linear regression analysis used to help explain the significance of the factors contributing to area development on subak sustainability. Equation model for multiple linear regressions is expressed by formula (1).

$$
\mathrm{Y}=\mathrm{bo}+\mathrm{b}_{1} \mathrm{X}_{1}+\mathrm{b}_{2} \mathrm{X}_{2}+\ldots+\mathrm{b}_{6} \mathrm{X}_{6} \ldots \ldots
$$

$Y=$ Subak sustainability

$\mathrm{X}_{1}=$ Proximity of subak location to tourism center

$\mathrm{X}_{2}=$ Existence of road in subak area

$\mathrm{X}_{3}=$ Existence of socio-economical facilities

$\mathrm{X}_{4}=$ Population density

$\mathrm{X}_{5}=$ Population growth

$\mathrm{X}_{6}=$ Percentage of non-agricultural families

bo $=$ Constanta

$\mathrm{b}_{1}, \mathrm{~b}_{2}, \mathrm{~b}_{3} . . \mathrm{b}_{6}=$

Regression coefficient value of $X_{1}, X_{2}, X_{3} \ldots \ldots . . . X_{6}$

Calculation of Constanta and regression coefficient values was carried out by utilizing SPSS version 15 program software. The influential power of each variable $(\mathrm{X})$ was indicated by conducting $t$ test with significance level of $10 \%$ and degree of freedom/db $=\mathrm{n}-1-\mathrm{k}(\mathrm{n}=$ number of subject and $\mathrm{k}=$ number of predictor/X). Meanwhile, to simultaneously measure the influential power of all predictors (X), either $F$ test or Anava test was conducted with significance level of $5 \%$.

\section{Result and Discussion}

\section{Spatial Pattern of Subak Sustainability Level}

Subak sustainability level is highly determined by the sustainability and manifestation of THK values harmoniously in the life of subak. Subak sustainability was analyzed by considering five 
aspects/dimensions derived from THK values, including cultural sustainability, social sustainability, economical sustainability, technical sustainability, and natural-physical sustainability. The result of the research on subak sustainability level is presented in Table 1 and Table 2.

Data in Table 1 show that out of 69 subaks observed, 32 subaks (46.38\%) have high sustainability, 25 subaks $(36.23 \%)$ have medium sustainability, and 12 ones (17.39\%) have low sustainability). In spite of the fact that 32 subaks appear with high sustainability, the empirical field observation indicates that nearly all subaks are under a threat of danger resulted from area transformation as well as dynamic and accelerative human life. Unesco (Bali Post, 2014) even gives 'yellow light' for Balinese subak for the absence of stakeholder's real actions, especially the government, to protect subak which has been granted as world cultural heritage.

In Table 2 shows that cultural sustainability as a representation parhyangan component were the highest compared pawongan components and palemahan. The results are consistent with the findings of Astra Wesnawa (2010) that parhyangan components in micro settlement in coastal areas and plain areas in Buleleng Regency is still strong survive in accordance with normative concept. While the components pawongan and palemahan began to change the direction economically.

Rapid transformation of area and life posing a threat to subak sustainability are triggered by some interrelated factors. To begin with, there are globalization and Green Revolution policies which carry market economic or capitalist economic system. Secondly, the local government's policies biased on tourism and are not able to accommodate agricultural sectors' interest (subak). Thirdly, spatial planning policies enacting research area as a part of metropolitan area of Sarbagita (Denpasar, Badung, Gianyar, Tabanan) are set based on President Regulation No. 45 Year 2011, and they, hence, potentially force productive agricultural fields. Finally, social and economical condition of farmers, specifically their farming income, can no longer meet a demand of the ever-increasing life expenses, while working opportunity and salary rate in non-agricultural sectors are widely opened.

Tabel 1. Distribution of the Number of Subaks According to THK Sustainability Level for Each Zone

\begin{tabular}{lllll}
$\begin{array}{c}\text { Subak } \\
\text { Sustainability }\end{array}$ & \multicolumn{4}{c}{$\begin{array}{c}\text { Short Zone } \\
\text { Zone }\end{array}$} \\
\hline 1. High & $2(9.09)$ & $13(48.15)$ & $17(85.0)$ & $32(46.38)$ \\
2. Medium & $8(36.36)$ & $14(51.85)$ & $3(15.0)$ & $25(36.23)$ \\
3. Low & $12(54.55)$ & - & - & $12(17.39)$ \\
\hline \multicolumn{1}{c}{ Total } & $22(100.0)$ & $27(100.0)$ & $20(100,0)$ & $69(100.0)$ \\
\hline
\end{tabular}

Source : Result of data analysis. Note $:()=$ Percentage.

Tabel 2. Distribution of the Mean Scores of Subak Sustainability Level of Each Zone

\begin{tabular}{lcccc}
\multicolumn{1}{c}{\begin{tabular}{c} 
Component of Subak \\
\multicolumn{1}{c}{ Sustamability }
\end{tabular}} & \multicolumn{3}{c}{ Mean Score of Each Zone } & Mean \\
& Short & Trantitional & Long & Scores \\
\hline 1. Cultural Sustainability & 2.4 & 3.2 & 3.6 & 3.1 \\
2. Social Sustainability & 2.2 & 3.1 & 3.5 & 2.9 \\
3. Economic Sustainability & 1.7 & 2.2 & 2.5 & 2.1 \\
4. Technical Sustainability & 2.1 & 2.9 & 3.3 & 2.8 \\
5. Natural Physical Sustainability & 2 & 2.8 & 3.3 & 2.7 \\
\hline \multicolumn{1}{c}{ Mean Scores } & 2.1 & 2.9 & 3.3 & 2.8 \\
\hline
\end{tabular}

Source : Result of data analysis. 
Spatial distribution of subak sustainability level indicates zoning-based grouping pattern. In near zone, the subak sustainability grouping is low, however, in transition zone; it is dominated by medium subak sustainability. Meanwhile, in far zone, the subak sustainability is high. The same pattern is also presented on the average score, in which the score for subak sustainability is 2.1 in near zone, 2.9 in transition zone, and 3.3 in far zone. The lowest average score is in near zone, while the highest one is in far zone. Spatial pattern of those three zones is visualized in Figure 1.
The spatial pattern of subak sustainability level as presented in Figure 1 is related to the fact that the area of Kuta belongs to major urban area and tourism center which functions as the key factor of international-scaled economic activities. The area of Kuta is the area of growth center in Badung regency, which possesses great backwash effect and spread effect on resource development in the surrounding areas. The closer an area to the center point is, the higher the transformation level of will be.

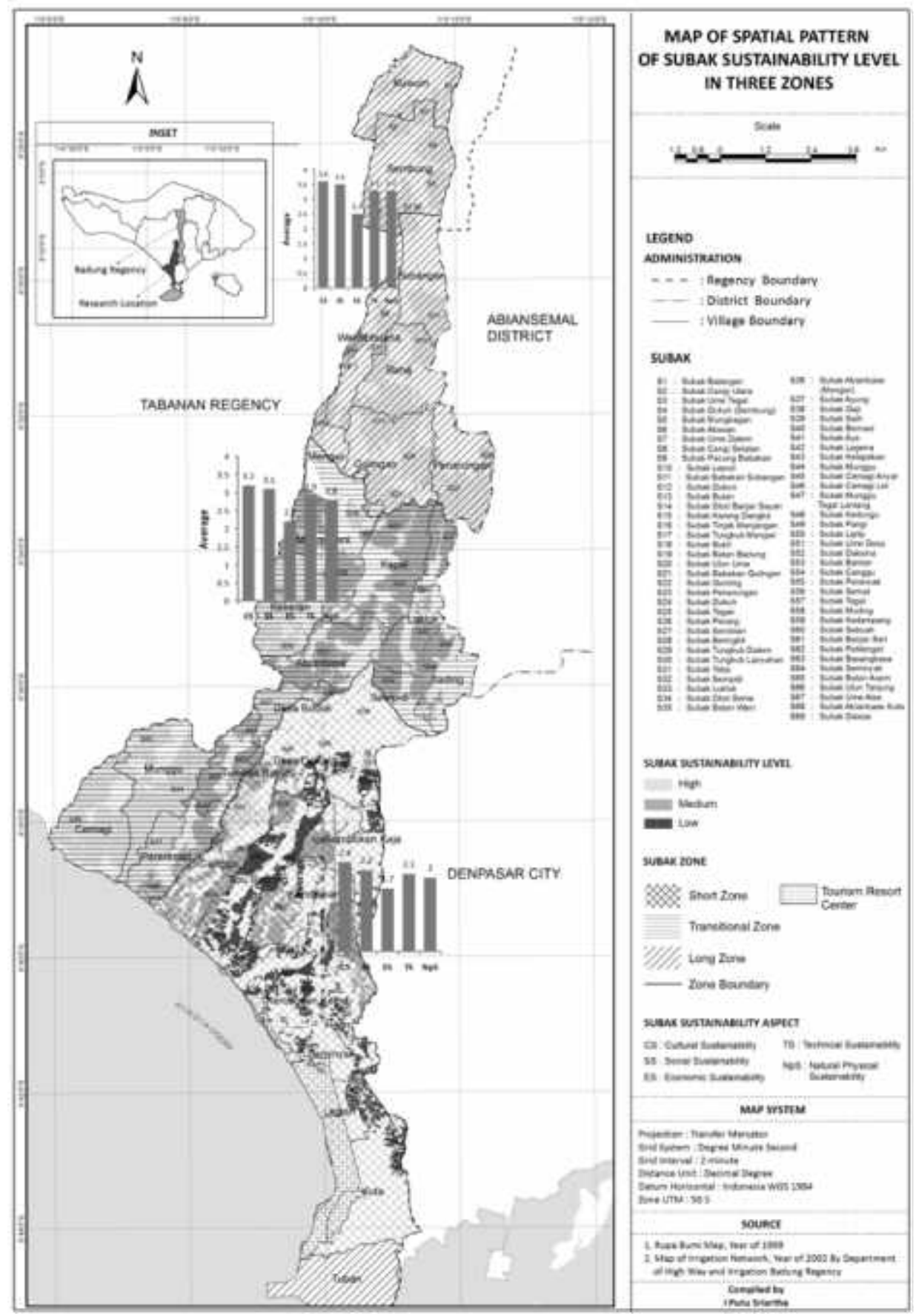

Figure 1. Spatial Pattern of Subak Sustainability Level 


\section{Components and Elements of THK Performing as Determinants for Subak Sustainability}

Subak, based on the philosophy of THK, consists of complex components and elements. Hence, it is required to identify the components and elements which function as main determinants for subak sustainability, which will be used as a guide for spatial priority to maintain it. The components and elements of $T H K$ analyzed with AHP technique are presented in Table 3, and the results are presented in Figure 2.

Having examined Figure 2, we conclude that two main elements to determine subak sustainability are controlling conversion of rice terraces with significance level of $24 \%$ and striving for irrigation water sufficiency with significance level of $21 \%$.

This means that setting priority to handle threat on subak sustainability should begin with making an effort to maintain rice terraces and irrigation water. In subak with high sustainability, rice terraces and water should be preserved exclusively for agricultural purpose and used as agricultural area/ eternal subak. In subak with medium sustainability, rice terraces and water can be used restrictively and conditionally for non-agricultural purposes. In subak with low sustainability, rice terraces and water can be utilized for non-agricultural activities without strict conditions, as required in high and medium subak sustainability.

Tabel 3. Components and Elements of THK that Determine Subak Sustainability

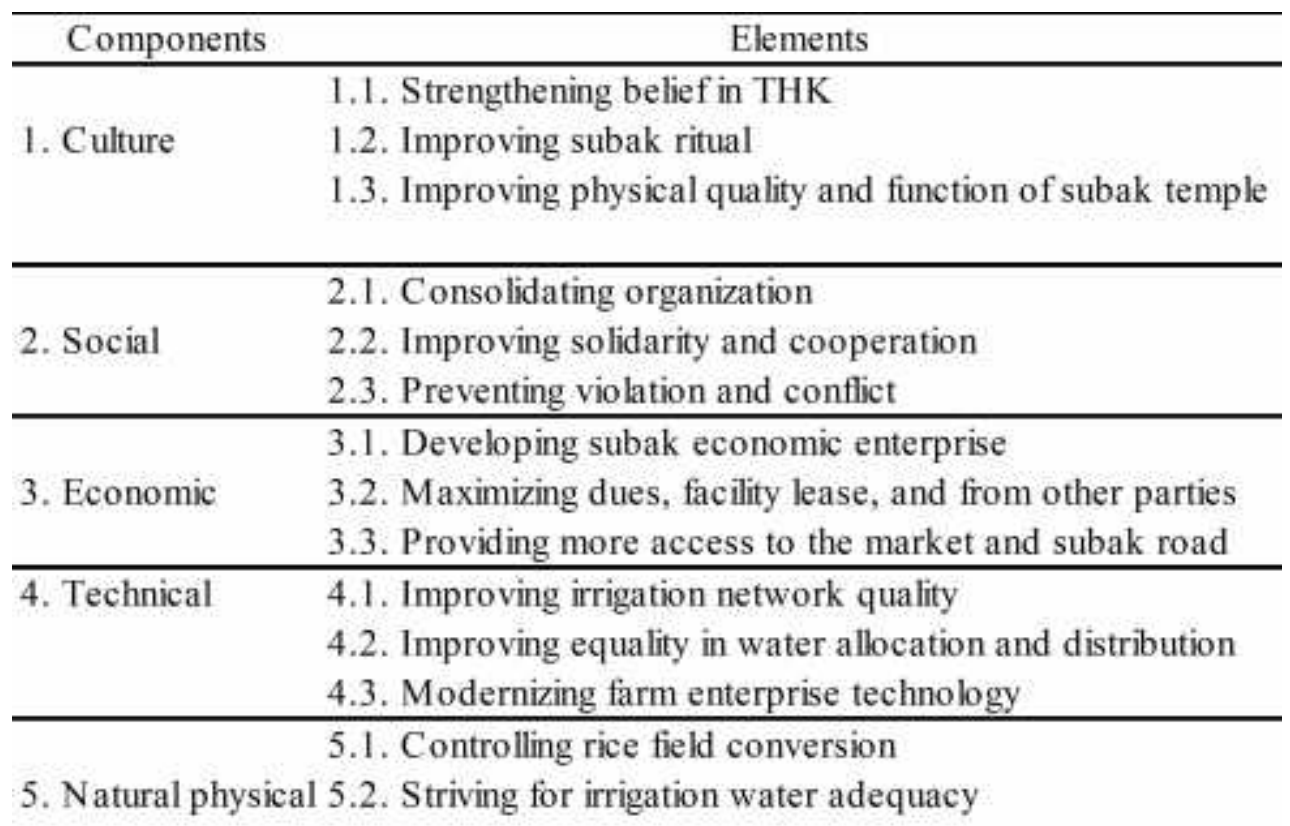

5.3. Preventing land and water pollution disturbance 


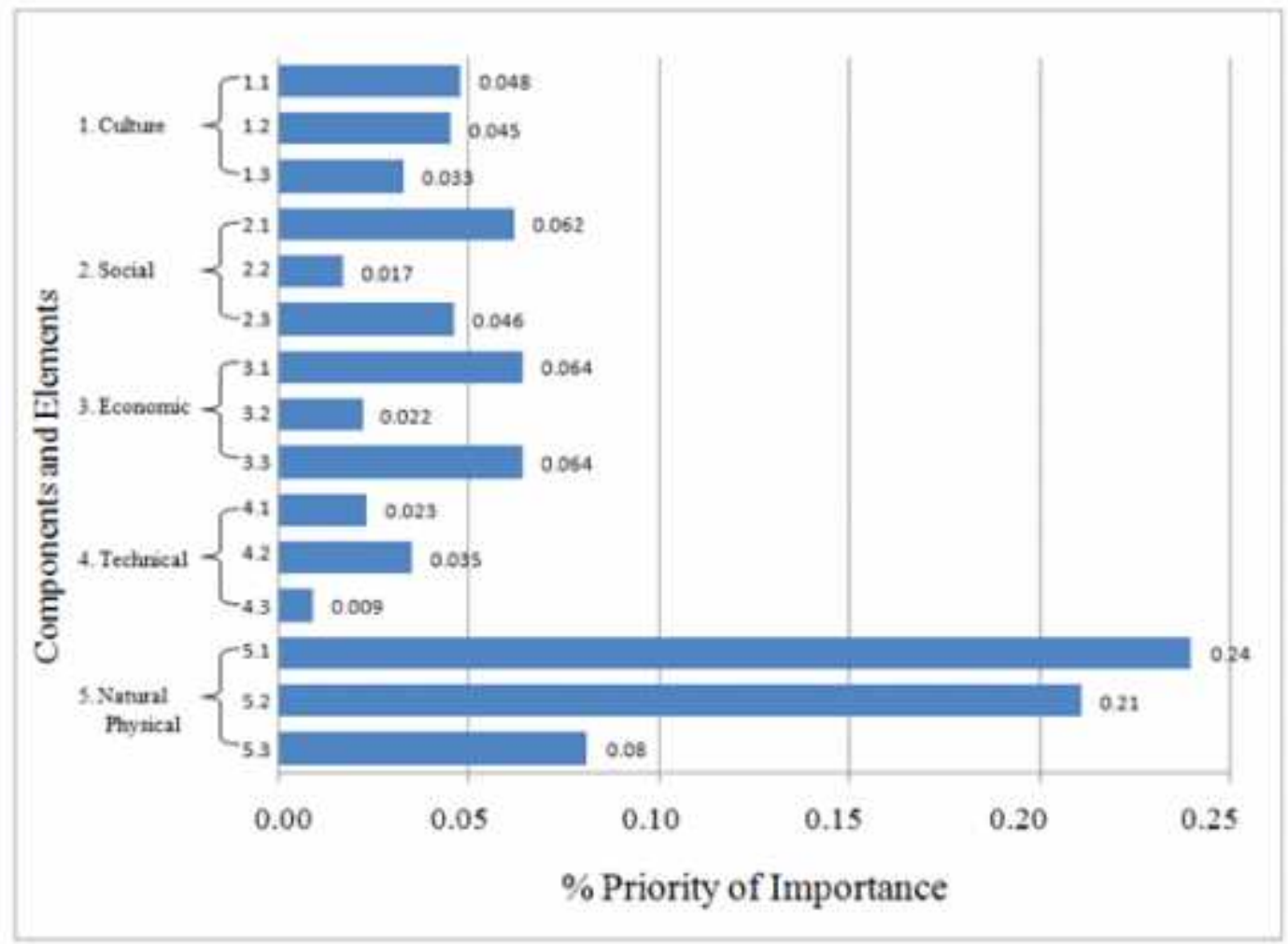

Figure 2. Relative Importance of Components and Elements of Subak Sustainability Determinants

\section{Factors of Area Development Attributable to Subak Sustainability}

Research on the effect of external factors, especially area development factors, on irrigation system sustainability, like subak, is still limited. This research determines 6 factors of area development which are estimated to put an effect on subak sustainability, including: proximity of subak location to tourism center $\left(\mathrm{X}_{1}\right)$, existence of road $\left(\mathrm{X}_{2}\right)$, existence of socio-economical facilities $\left(\mathrm{X}_{3}\right)$, population density $\left(\mathrm{X}_{4}\right)$, population growth $\left(\mathrm{X}_{5}\right)$, and percentage of nonagricultural family $\left(\mathrm{X}_{6}\right)$. The result of the data analysis with multiple linear regression analysis technique is presented in Table 4.

$T$ test or $t$ significance value ( $t$ Sig.) as displayed in Table 4 reveals that it is only variable $\mathrm{X}_{5}$ which has insignificant or unconvincing effect ( $t$ Sig. $>10 \%)$, while the other 4 variables show significant correlation $(t$ Sig. $<10 \%)$. Of the five variables having strong effects, variable $X_{1}$ shows positive direction, while the other 4 variables, i.e. $X_{2}, X_{3}, X_{4}$ and $X_{6}$ show negative direction.
The role of variables $\mathrm{X}_{1}, \mathrm{X}_{2}, \mathrm{X}_{3}, \mathrm{X}_{4}, \mathrm{X}_{6}$ as predictors on the shift of subak sustainability level is indicated by the regression coefficient value or beta value (Table 4). Regression coefficient of $X_{1}=0.270$ means that if the distance of subak area is one unit farther, the subak sustainability level increases $27 \%$, and conversely. Regression coefficient of $\mathrm{X}_{2}$ $=0.255$ means that if the existence of road increases one unit, the subak sustainability level decreases $25.5 \%$, and conversely. In the same way, prediction and estimation of $\mathrm{X}_{3}, \mathrm{X}_{4}$, and $\mathrm{X}_{6}$ variables on the shift of subak sustainability level can be interpreted identically to the meaning of the effect of $\mathrm{X}_{2}$.

By conducting $F$ test or examining $F$ significance value $=0.000$ (Table 4$)$, it is found that simultaneously, the six $\mathrm{X}$ variables contribute significantly on the shift of subak sustainability. The contribution value is indicated by $\mathrm{R}^{2}$ (adjusted $R$ square) amounting to 0.878. This means that the shift of subak sustainability level of $87.8 \%$ is caused by the six variables simultaneously, while the rest, $12.2 \%$, is caused by other variables beyond this research scope. 
Tabel 4. The Result of Multiple Regression Analysis on the Effect of External Factors on Subak Sustainability

\begin{tabular}{|c|c|c|c|c|c|}
\hline Multiple $\mathrm{R}=$ & $\begin{array}{l}0.943 \\
0.880\end{array}$ & Adjusted R Square = & $\begin{array}{l}0.878 \\
12.81\end{array}$ & $\begin{array}{r}F= \\
\text { Sio. } F=\end{array}$ & $\begin{array}{r}82.381 \\
0\end{array}$ \\
\hline & 0.889 & Standar Error $=$ & 12.81 & Sig. $F=$ & \\
\hline Variable & B & SEB & Beta & $\mathrm{t}$ & Sig.t \\
\hline $\mathrm{X}_{1}$ & 1.395 & 0.426 & 0.27 & 3.276 & 0.002 \\
\hline $\mathrm{X}_{2}$ & -1.35 & 0.432 & -0.26 & -3.130 & 0.003 \\
\hline $\mathrm{X}_{3}$ & -0.03 & 0.011 & -0.28 & -3.083 & 0.003 \\
\hline $\mathrm{X}_{4}$ & -0.27 & 0.148 & -0.1 & -1.838 & 0.071 \\
\hline$X_{5}$ & -0.53 & 0.945 & 0.026 & 0.374 & 0.709 \\
\hline$x_{6}$ & -0.23 & 0.106 & -0.19 & -2.173 & 0.034 \\
\hline Constant & 184.4 & 11.084 & - & 16.639 & 0 \\
\hline
\end{tabular}

\section{Conclusion and Recommendation}

Development of the region in the form of urban and tourism development which goes rapidly is threatening the sustainability of water control system in the study area. Subak sustainability spatial distribution level forms a clustered pattern with different value between close zones, transition zone, and the zone away from the tourism center. THK components and elements which become the top priority of the protection of Subak is to control over wetland function and ensure adequate irrigation water. There are five factors of region development that strongly influence Subak sustainability, namely: distance of Subak region into a tourism center, the road, economic facilities, population density, and the percentage of non-farm families. Simultaneously, these five factors contributing $87.8 \%$ to Subak sustainability, while the remaining $12.2 \%$ is explained by other factors outside the scope of this study.

Government has to be the institution with the most responsibility to determine the Subak sustainability because this insttitution has the political authority to plan and set the development policy. It is recommended that the government conduct a policy priority to develop the agricultural sector and synergize it with the tourism sector. Steps that need to be done are: (1) establishing wetland zoning and Subak sustainability through legislation, (2) Revising or creating new legislation about Subak economic empowerment and autonomous and legal institution, (3) Revising the regulation on protection of local agricultural products produced by farmers.

\section{Acknowledgement}

The writers would like to express their gratitude to Badung Local Government who have helped with the data, facilities, and personel for the research actitivity. The Gratitude is also expressed to Head of Research and Community Service of Directorate General of Higher Education, and Head of Research Institution of Ganesha University of Education who have financed some of the themes of this research through Higher Education Decentralization Funding.

\section{References}

Ahimsa-Putra, H.S. 1999. Strategies to Transfer Subak Farming System to Non-Balinese Societies. In Sahid Susanto (Ed) : A Study of the Subak As An Indigenous Cultural, Social. And Technological System To Establish A Culturally Based Integrated Water Resources Management, Volume I. Yogyakarta : Faculty of Agricultural Technology, Gadjah Mada University. 
Artha AW, Wayan I, Lorenzen RP, and Lorenzen S. 2006. Past, Present And Future-Perspectives of Balinese Rice Farming. Dalam Sumarno, Suparyono, Achmad M. Pagi, Made Oka Adnyana (Ed) : Rice Industry, Culture, and Environment, Book 1. Proceedings of the International Rice Conference, September 12-14, 2005, Tabanan Bali. Indonesian Agency for Agricultural Research and Development in Cooperation with International Rice Research Institute.

Ambler JS. 1992. Dinamika Irigasi Petani : Kerangka dan Prinsip-Prinsip Kelembagaan. Dalam John S. Ambler (Ed) : Irigasi di Indonesia : Dinamika Kelembagaan Petani. Jakarta : LP3ES. Anonim. 2012. Unesco Sahkan Subak Bali Sebagai Warisan Budaya Dunia. in http://www.dikti.go.id/ ?p=2671\&lang=id. [20 August 2012)]

ANTARA. 2012. Unesco Sahkan Subak Bali Sebagai Warisan Budaya Dunia. in http://www.dikti.go.id/ ?p=2671\&lang=id. [ 20 August 2012]

Wesnawa IGA. 2010. Perubahan Lingkungan Permukiman Mikro Daerah Perkotaan Berbasis Konsep Tri Hita Karana Di Kabupaten Buleleng Bali. Forum Geografi, Vol. 24, No. 2, Desember 2010 : 111-118.

Baharsyah S. 2005. Local Wisdom As An Important Social Capital In Rice-Based Agriculture Development. Dalam Sumarno, Suparyono, Achmad M. Pagi, Made Oka Adnyana (Ed) : Rice Industry, Culture, and Environment, Book 1. Proceedings of the International Rice Conference, September 12-14, 2005, Tabanan Bali. Indonesian Agency for Agricultural Research and Development in Cooperation with International Rice Research Institute.

Bali Post. 2014. Unesco Beri Lampu Kuning Kepada Subak. Terbitan Nomor 266 Tahun Ke 66, Senin Tanggal 26 Mei 2014. Denpasar.

Bastakoti, Ram C., Ganesh P. Shivakoti, Louis Lebel. 2010. Local Irrigation Management Institutions Mediate Changes Driven by External Policy and Market Pressures in Nepal and Thailand. Environmental Management (2010) 46:411-423. DOI 10.1007/s00267-010-9544-9. @ Springer Science+Busisiness Media, LLC 2010.

Geertz, C. 1972. The Wet and the Dry : Traditional Irrigation In Bali and Marocco. Dalam Human Ecology I. New York : Plenum Publising Corporation.

Geertz, C. 1979. Negara, The Theatre State in Nineteenth-Century Bali. Princeton : Princeton University Press.

Geertz, C. 1980. Organization of the Balinese Subak. In E.W Coward, JR. (ed) : Irrigation and Agricultural Development in Asia. Ithaca : Cornell University Press.

Kasryno, Faisal., Effendi Pasandaran, dan Achmad M. Fagi. 2003. Local Wisdom of the Subak Syatem In Bali : A Model of Just and Sustainable Rural Development. Dalam Faisal Kasryno, Effendi Pasandaran, dan Achmad M. Fagi (Penyunting) : Subak dan Kerta Masa, Kearifan Lokal Mendukung Pertanian Berkelanjutan. Jakarta : Yayasan Padi Indonesia (YAPADI).

Lansing, JS. 1987. Balinese Water Temples and the Management of Irrigation. Dalam American Antropologist No. 89.

Lansing, JS and Therese A. de Vet. 2012. The Functional Role of Balinese Water Temples : A Response to Critics. Hum Ecol (2012) 40: 453-467, DOI 10.1007/s10745-012-9469-4. Published online: 1 May 2012, (C) Springer Science+Business Media, LLC 2012. [16 October 2013]

Lorenzen, Rachel P. And Stephan Lorenzen. 2010. Changing Realities - Perspectives on Balinese Rice Cultivation. Hum Ecol (2011) 39: 29-42, DOI 10.1007/s10745-010-9345-z. Published online: 17 August 2010, @ Springer Science+Business Media, LLC 2010. [16 October 2013] 
MacRae, Graeme S. and I.A.W. Arthawiguna. 2011. Sustainable Agricultural Development in Bali : Is the Subak an Obstacle, an Agent or Subject?. Hum Ecol (2011) 39: 11-20, DOI 10.1007/s10745-011-3986-y. Published online: 1 Marcht 2011, (C) Springer Science+Business Media, LLC 2011. [16 October 2013]

Mawardi, Muhjidin. 1999. Socio-Economic Change And Its Effect on Sustainability of Subak System. In Sahid Susanto (Ed) : A Study of the Subak As An Indigenous Cultural, Social. And Technological System To Establish A Culturally Based Integrated Water Resources Management, Volume III. Yogyakarta : Faculty of Agricultural Technology, Gadjah Mada University.

Purnama, Setyawan. 2009. Neraca Air Pulau Bali. Jurnal Forum Geografi Vol. 23, No. 1, Juli 2009 : 57-70.

Saaty, T.L. 1994. Fundamentals of Decision Making and Priority Theory with the Analytic Hierarchy Process. Pittsburgh (USA) : RWS Publications.

SEARCA. 1995. Working Paper on Sustainable Agriculture Indicators. Laguna, Philippines : SEAMEO Regional Center for Graduate Study and Research in Agriculture.

Susanto, S. 1999. Methodological Approach of Field Investigation on Developing Starategies of Culturally Based Water Resources Management. In Sahid Susanto (Ed) : A Study of the Subak As An Indigenous Cultural, Social. And Technological System To Establish A Culturally Based Integrated Water Resources Management, Volume III. Yogyakarta : Faculty of Agricultural Technology, Gadjah Mada University.

Susanto, S. 2000. Pemberdayaan Institusi Tradisional Subak Untuk Pembangunan Pertanian Irigasi Yang Berkelanjutan. VISI : Sumberdaya Air, Lahan, dan Pembangunan Nomor 19, September 2000.

Sutawan, N. 2005. Subak Menghadapi Tantangan Globalisasi, Perlu Upaya Pelestarian dan Pemberdayaan Secara Lebih Serius. Dalam I Gede Pitana dan I Gede Setiawan AP., (Ed) : Revitalisasi Subak Dalam Memasuki Era Globalisasi. Yogyakarta : ANDI OFFSET.

Sutawan, N. 2008. Organisasi dan Manajemen Subak Di Bali. Denpasar : Pustaka Bali Post.

Windia, W. 2002. Transformasi Sistem Irigasi Subak Yang Berlandaskan Konsep Tri Hita Karana. Disertasi (tidak dipublikasikan). Yogyakarta: Universitas Gadjah Mada.

Windia, W. 2005. Rekonstruksi Subak Dalam Menghadapi Era Globalisasi. Dalam I Gede Pitana dan I Gede Setiawan AP., (Ed) : Revitalisasi Subak Dalam Memasuki Era Globalisasi. Yogyakarta : ANDI OFFSET.

Windia, W. 2008. Menuju Sistem Irigasi Subak Yang Berkelanjutan Di Bali. Orasi Ilmiah. Disampaikan dalam pidato pengukuhan jabatan guru besar dalam bidang ilmu sosial ekonomi pertanian pada Fakultas Pertanian Universitas Udayana tanggal 29 Maret 2008. Denpasar : Universitas Udayana. 